\title{
Toxicological assessments of the aqueous extract of Boswellia dalzielli stem bark on the liver and kidney of male mice
}

\author{
L. J. Goje ${ }^{1 \star}$, P. E. Ghamba ${ }^{2}$, D. N. Bukbuk ${ }^{3}$ and I. Lai ${ }^{4}$ \\ ${ }^{1}$ Department of Biochemistry, Gombe State University, P.M.B. 127, Gombe, Gombe State, Nigeria. \\ ${ }^{2}$ WHO National Polio Laboratory, University of Maiduguri Teaching Hospital, P.M.B. 1414, Maiduguri, Borno \\ State, Nigeria. \\ ${ }^{3}$ Department of Microbiology, University of Maiduguri, Maiduguri, Borno state, Nigeria. \\ ${ }^{4}$ Department of Human Physiology, Gombe State University, P.M.B. 127, Gombe, Gombe State, Nigeria.
}

Accepted 30 August, 2012

\begin{abstract}
The study was conducted to determine the phytochemical constituents and also to assess the toxicity of the aqueous extract of Boswellia dalzielli stem bark on the liver and kidney of male mice. Healthy male mice weighing between 45 to $50 \mathrm{~g}$ were used. The mice were grouped into four different groups, each containing four mice, respectively. Different concentrations $(200,400$ and $600 \mathrm{mg} / \mathrm{kg})$ of the aqueous extract of $B$. dalzielli stem bark were orally administered, respectively according to group, at the interval of $12 \mathrm{~h}$ per day, whereas the other group was not given any treatment and this served as the normal control, providing a baseline data. The experiment lasted for two weeks after which the animals were sacrificed by human decapitation. The serum was obtained and used for the analysis of the parameters of hepatic and renal functions, respectively. The results of the phytochemical screening revealed the presence of alkaloid, flavonoid, tannins, saponins, balsam, cardiac glycoside, terpenes, steroids, resins, and phenols. All the treatment groups showed an elevated serum aspartate transaminase (AST) and a low serum alanine transaminase (ALT), and ALP was $(p<0.05)$, indicating possibly a damage to the liver. Also, the treatments showed a low serum urea and a normal creatinine level $(p<0.05)$. Therefore, it was concluded that the extract had some toxic effects on the liver but had no toxic effect on the kidney of the mice.
\end{abstract}

Key words: Boswellia dalzielli, phytochemical constituents, toxicity, hepatic and renal functions.

\section{INTRODUCTION}

Medicinal plants are various plants thought by some to have medicinal properties, but few plants or their phytochemical constituents have been proven and approved by some regulatory agencies such as National Agency for Food and Drug Administration and Control (NAFDAC) in Nigeria, United State Food and Drug Administration and the European Food Safety Authority to have medicinal effects (Odesanmi et al., 2009). For centuries, medicinal plants have been the most important

*Corresponding author. E-mail: lazgoje@yahoo.com. Tel: +234070-315-452-20. source of life saving drugs for the majority of the world's population (Coomb's,1989;Tripathi and Tripathi, 2003). Plants have been an important source of medicine for thousands of years that even currently; the World Health Organization (WHO) estimated that up to $80 \%$ of people over the world still rely on traditional remedies such as herbs for their medicines (Odesanmi et al., 2009).

Medicinal plants have one or more parts with medicinal properties, and of the pharmacologically active principles found in plant kingdom, higher plants are arguably the most important group (Sofowora, 1993). They also cover the wide range of pharmacological effects which remain poorly understood. Out of the estimated 800,000 plant species on earth, about a quarter have been categorized 
and only a small fraction of these have been examined for pharmalogical efficacy (Hussin, 2001;Goldman,2001). Toxicity studies which is the study of the symptoms, mechanisms, treatment and detection of poisoning, especially the poisoning of people, is done usually by the assessment of the level of damage done to the liver and the kidneys which are the chief organs responsible for the metabolism of xenobiotics in the body (Nwogwu et al., 2008).

The plant $B$. dalzielli called Frankincense tree in English, 'Ararrhabi' or 'Hano' in Hausa, 'Tiya Shigo' in Dadiya (Gombe), and 'Juguli' in Fulfulde (Adamawa) is a plant (growing up to $13 \mathrm{~m}$ high) of the wooded savanna, with characteristically pale papery bark, peeling and ragged, locally abundant in northern Nigeria, Cameroun and Ubangishari (Murray, 1995). The small white flowers which may appear while the tree is leafless are fragranced (Johnson, 1997).

The tree is sometimes planted in northern parts of Ivory coast and may sometimes be planted as a village stockade on the vocal peak massif of northern Nigeria and often as a live fence to bring prosperity (ba-samu) or to prevent (Hanu) bad luck, hence the Hausa names. The name "hanu" may also have significance to certain prejudices regarding the use of the resin (Murray, 1995). The bark contains whitish exudates which dries readily and is friable.

It is fragranced and is burnt alone or with other fragrant resin to fumigate clothing and in room to drive out flies, mosquitoes etc. (Murray, 1995). It is used by catholic mission as a substitute for true incense. It may be added to the juice of acacia berries used in ritual mummification practice by various tribes in northern Nigeria. When mixed with the stem bark extract of Vertex doniana sweet (Verberacea), it forms an important ingredient of malam's ink (Greenwald, 1997).

The bark decoction is used as an antiseptic wash for sores in Ivory Coast, and it is an ingredient of a complicated prescription for leprosy. In northern Nigeria, the bark is boiled up in large quantity to make a wash for fever, rheumatism etc and the fluid is taken internally for gastro intestinal troubles (Johnson, 1997). The Fulani tribe of northern Nigeria uses the cold infusion of the stem bark for snake bite treatment (Moses et al., 2005). The fresh bark of the root is chewed in Dadiya (Gombe), Nigeria to cause vomiting after a few hours and thus relief symptoms of giddiness and palpation. Both the root and bark are known to be antidotes for arrow poison; for instance the root is combined with that of Daniella oliveri (Rolf) Hutch and Dalzielli (Leguminoidea; caesolpiniodeae) to make a decoction which is drunk by the wounded person, and is said to be effective without causing diarrhea (Murray, 1995). In northern Ivory Coast, it has been reported to be useful in the treatment of arthritis, rheumatism, asthma and also used in combination with Hibiscus sabdariffa for the treatment of syphilis (Moses et al., 2005).

\section{MATERIALS AND METHODS}

\section{Plant}

The plant sample was collected from Maitunku Hill Bambam, Dadiya District of Gombe State using matchet. The plant was identified by Mr. Daniel M. Mshelbwala, Federal School of Forestry and Horticulture, Department of Forestry, Jos, and was further authenticated by Prof. S. S. Sanusi, Department of Biological Sciences, University of Maiduguri, Borno State. The stem bark of the plant was air dried in the laboratory, Department of Biochemistry, University of Jos. It was then ground into powder using pestle and mortar.

\section{Extraction of the aqueous extract of the plant}

Twenty grams $(20 \mathrm{~g})$ of the stem bark powder was soaked in 200 $\mathrm{mL}$ of distilled water and was allowed to stand for $48 \mathrm{~h}$ after which it was filtered using Whatman No. 1 filter paper. The filtrate was concentrated using a rotary evaporator maintained at $40^{\circ} \mathrm{C}$.

\section{Experimental animals}

The twenty (20) healthy male mice used for this experiment were purchased from the animal farm, university of Jos, Plateau State. The mice weighed between 45 to $50 \mathrm{~g}$. They were maintained on commercial preparations of growers' marsh containing 54\% carbohydrate, $10 \%$ proteins, $19 \%$ fat, $20 \%$ fibre, $2 \%$ minerals and $1 \%$ vitamin premix. The mice were divided into four groups, each consisting of four mice, on the basis of their weight. The groups were treated by oral administration of the aqueous extract of the plant as follows:

Group 1- This group was given $200 \mathrm{mg} / \mathrm{kg}$ of the plant extract every twelve hours for 14 days;

Group 2- This group was administered $400 \mathrm{mg} / \mathrm{kg}$ of the plant extract every twelve hours for 14 days;

Group 3- This group was administered $600 \mathrm{mg} / \mathrm{kg}$ of the plant extract every twelve hours for 14 days;

Group 4- The mice in this group were fed normal without being administered with the plant extract for the period of the research, and the parameters from this group served as baseline data.

\section{Phytochemical screening}

Preliminary qualitative phytochemical screening was performed on the aqueous extract of the stem bark of $B$. dalzielli. The methods of screening used in this study were mainly qualitative analysis and are based on Trease and Evans (1984) and Sofowora (1986). These methods involved using reagents known to produce a particular color change which is distinct to that particular compound. The test was performed to detect the presence of alkaloids, flavonoid, tannins, saponins, cardiac glycosides, terpenes and steroids, Balsam, phenols, and Resins.

\section{Test for alkaloids}

Dregendorf test was used to detect the presence of alkaloids. To 2 $\mathrm{ml}$ of the extract, few drops of Dregendorf reagent were added and observed for orange coloration.

\section{Test for flavonoids}

The general test was used to detect for the presence of flavonoids. 
To $2 \mathrm{ml}$ of the extract, small quantity of magnesium chips was added followed by the addition of $2 \mathrm{ml}$ of Conc. HCl. The solution formed was observed for reddish coloration which indicated the presence of flavonoids.

\section{Test for tannins}

The ferric chloride test was used to detect the presence of tannins. $2 \mathrm{ml}$ of the extract was diluted with $8 \mathrm{ml}$ of distilled water (in a ratio of $1: 4)$ and few drops of $10 \%$ ferric chloride solution was added and it was observed for blue or green precipitate or coloration which showed the presence of tannins.

\section{Test for saponins}

To $2 \mathrm{ml}$ of the extract, $5 \mathrm{ml}$ of distilled water was added and shaken vigorously for 2 min after which few drops of olive oil was added and the formation of an emulsion showed the presence of saponins.

\section{Test for cardiac glycoside}

Salkowski test was used to detect the presence of cardiac glycoside. $0.5 \mathrm{~g}$ of the extract was dissolved in $2.0 \mathrm{ml}$ of chloroform after which sulphuric acid was carefully added to form a lower layer. A reddish brown color at the interphase indicated the presence of cardiac glycoside.

\section{Test for terpenes and steroids}

Liebermann-Burchard test was employed. To $2.0 \mathrm{ml}$ of the extract, $1 \mathrm{ml}$ of acetic anhydride and Concentrated Tetraoxosulphate (VI) acid $\left(\mathrm{H}_{2} \mathrm{SO}_{4}\right)$ was carefully added down the side of the test tube and it was observed for reddish brown coloration at the interphase which indicated the presence of terpenes and steroids.

\section{Test for balsam}

Three (3) drops of alcoholic ferric chloride was added to $2.0 \mathrm{ml}$ of the extract. A dark green coloration showed the presence of balsam.

\section{Test for phenols}

To $2.0 \mathrm{ml}$ of the extract, $2 \mathrm{ml}$ of ferric chloride was added and it was observed for the formation of deep violet coloration, which confirmed the presence of phenols.

\section{Test for resins}

To $2.0 \mathrm{ml}$ of the extract $2 \mathrm{ml}$ of acetic anhydride was added followed by addition of few drops of concentrated sulphuric acid and the solution was observed for the formation of violet coloration which confirmed the presence of resins.

\section{Methodologies for the test of hepatic and renal functions}

Determination of serum alkaline phosphatase activity by colorimetric method (Reitman and Frankel, 1957)

A reagent kit by Randox was used according to the recommendations of the Dustche Gesselchaft fur Klinische chemie.
Principle: The underlining principle is as follows:

P-nitrophenyl phosphate $+\mathrm{H}_{2} \mathrm{O}_{\text {ALP }}$ phosphate + P-nitrophenol

The concentration of P-nitrophenol formed is measured colorimetrically at $405 \mathrm{~nm}$ and is proportional to the alkaline phosphatase activity. The buffer (diethalomine buffer) had concentration in the test of $1 \mathrm{mmol} / \mathrm{L}$ and $\mathrm{pH} 9.8$, while $\mathrm{MgCl}_{2}$ had concentration of $0.5 \mathrm{mmol} / \mathrm{L}$. The substrate P-nitrophenolphospate had concentration of $10 \mathrm{mmol} / \mathrm{L}$.

Procedure: $0.01 \mathrm{ml}$ of the test sample was added into a clean test tube followed by $0.5 \mathrm{ml}$ of the reagent and mixed, and then the initial reading of the absorbance was taken at $405 \mathrm{~nm}$ against air. A timer was started simultaneously and the absorbance was read again after 1,2 and $3 \mathrm{~min}$ at $37^{\circ} \mathrm{C}$.

Determination of aspartate amino transaminase (ASAT) by colorimetric method (Reitman and Frankel, 1957)

Reaction principle: The underlining principle is as follows:

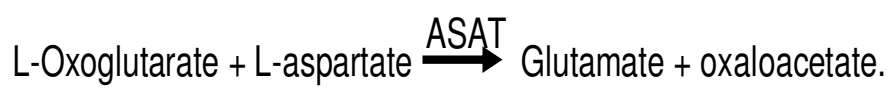

Aspartate amino transaminase activity is measured by monitoring the concentration of oxaloacetate hydrazone formed with 2,4dinitrophenyl hydrazine. A reagent kit containing phosphate buffer (10 mmol/L, pH 7.4), L-aspartate $(100 \mathrm{mmol} / \mathrm{L})$, L-oxoglutarate $(2$ $\mathrm{mmol} / \mathrm{L}), 2$,4-ditrophenyl hydrazine $(2 \mathrm{mmol} / \mathrm{L})$ and sodium hydroxide $(\mathrm{NaOH}) 0.4 \mathrm{M}$ was used. Sixteen grams $(16 \mathrm{~g})$ of $\mathrm{NaOH}$ was dissolved and made up to $1 \mathrm{~L}$ in distilled water.

Procedure: To each of the two clean test tubes marked 'test' and 'blank', $0.5 \mathrm{ml}$ of substrate buffer solution was placed and incubated at $37^{\circ} \mathrm{C}$ for $5 \mathrm{~min}$, then $0.2 \mathrm{ml}$ of the test sample was added to the test tube labeled 'test' and further incubated at $37^{\circ} \mathrm{C}$ for $30 \mathrm{~min}$. To all the test tubes, $0.5 \mathrm{ml}$ of dinitrophenyl hydrazine was added. 0.2 $\mathrm{ml}$ aliquot of serum was then added to the test tube labeled 'blank'. The mixture was shaken and allowed to stand at room temperature for 20 min after which $5 \mathrm{ml}$ of $0.5 \mathrm{M} \mathrm{NaOH}$ was added to each of the tubes and allowed to stand for $5 \mathrm{~min}$. The absorbance was measured at $540 \mathrm{~nm}$ after zeroing the instrument with distilled water.

Determination of serum alanine amino transaminase (ALAT) by colorimetric method (Reitman and Frankel, 1957)

Principle:

L-oxoglutarate + L-alanine $\stackrel{\text { ALT }}{\longrightarrow}$ L-glutamate + pyruvate

Alanine amino transaminase activity is measured by monitoring the concentration of pyruvate hydrazone formed with 2,4-dinitrophenyl hydrazine. Kit used contained Phosphate buffer $(10 \mathrm{mmol} / \mathrm{L}, \mathrm{pH}$ 7.4), L-alanine $(200 \mathrm{mmol} / \mathrm{L})$, L-oxoglutarete $(2.0 \mathrm{mmol} / \mathrm{L}), 2,4$ dinitrophenyl hydrazine (2 mmol/L) and $\mathrm{NaOH}(4 \mathrm{M})$

Procedure: To 2 test tubes marked 'test' and 'Blank', $0.5 \mathrm{ml}$ of buffer substrate solution was placed and incubated at $37^{\circ} \mathrm{C}$ for 5 
Table 1. Phytochemical screening test for the stem bark extract of Boswellia dalzielli.

\begin{tabular}{ll}
\hline Chemical group & Aqueous extract \\
\hline Alkaloid & + \\
Flavonoid & + \\
Tannins & + \\
Saponins & + \\
Balsam & + \\
Cardiac glycoside & + \\
Terpenes and steroids & + \\
Resins & + \\
Phenol & + \\
\hline
\end{tabular}

$+=$ present, $-=$ absent.

min. Then $0.1 \mathrm{ml}$ of the serum was added to the test and incubated for $30 \mathrm{~min}$. To all the test tubes, $0.5 \mathrm{ml}$ of 2,4-dinitrophenyl hydrazine was added. The mixture was shaken and allowed to stand at room temperature for $30 \mathrm{~min}$, and then $5 \mathrm{ml}$ of $\mathrm{NaOH}$ was added and allowed to stand for $5 \mathrm{~min}$. The absorbances were measured using a spectrophotometer at $540 \mathrm{~nm}$ after zeroing the instrument with distilled water at the same wave length.

\section{Determination of serum urea method of Natelson, modified by (Halora, 1988)}

Principle: Urea reacts with diacetyl monoxime in the presence of strong acids and oxidizing agents to produce a chromogen whose absorbance is directly proportional to the concentration of urea.

Procedure: To three clean dried test tubes marked test, blank and standard, $0.02 \mathrm{ml}$ of serum was placed in the tube marked 'test', $0.02 \mathrm{ml}$ of urea standard was placed in a tube marked 'standard' and $0.02 \mathrm{ml}$ of distilled water in the tube marked 'blank', then $0.1 \mathrm{ml}$ of diacetyl monoxime solution was added to all test tubes, followed by $5.0 \mathrm{ml}$ of the acid mixture. The tubes were kept in a boiling water bath for $15 \mathrm{~min}$ and then cooled in running water. The absorbance of the standard and test were read at $520 \mathrm{~nm}$ within the next $15 \mathrm{~min}$ against the reagent blank.

\section{Determination of serum creatinine (Jaffe, 1968) method}

Principle: Creatinine reacts with picric acid at an alkaline $\mathrm{pH}$ to produce a red colored complex; the absorbance of the complex is directly proportional to the amount of creatinine in the sample.

Procedure: The serum was first deproteinised by adding $1 \mathrm{ml}$ of $5 \%$ sodium tungstate, $1 \mathrm{ml}$ of $0.33 \mathrm{M} \mathrm{H}_{2} \mathrm{SO}_{4}$ and $1 \mathrm{ml}$ of distilled water to $1 \mathrm{ml}$ of the serum. The mixture was centrifuged at 3,000 $\mathrm{rpm}$ for $10 \mathrm{~min}$. The clear supernatant was then used for the determination of creatinine. To a clean dried test tubes marked test, standard and blank, $3.5 \mathrm{ml}$ of distilled water was added, then $0.5 \mathrm{ml}$ of creatinine standard was added to tube labeled 'standard' and 0.5 $\mathrm{ml}$ of protein-free serum was added to tube labeled 'test'. Then 1.0 $\mathrm{ml}$ of picric acid solution was added to all test tubes, followed by 1.0 $\mathrm{ml}$ of $\mathrm{NaOH}$. The tubes were mixed and allowed to stand for $15 \mathrm{~min}$ after which the absorbance of the test and standard were measured against reagent blank at $500 \mathrm{~nm}$.

\section{Statistical analysis}

Student's t-test was used to test for significant difference between the groups and the normal control at $P \leq 0.05$ using Statistical package for social sciences (SPSS).

\section{RESULTS}

The results of the phytochemical screening displayed in Table 1 showed the presence of alkaloid, flavonoid, tannins, balsam, cardiac glycoside, terpenes and steroids, resins, and phenol. The results of the toxicity studies of the effect of the oral administration of the aqueous extract of $B$. dalzielli stem bark on the indices of hepatic and renal functions of male mice at different concentrations of 200,400 and $600 \mathrm{mg} / \mathrm{kg}$ are shown in Tables 2,3,4,5 and 6 respectively. The result showed that the serum level of ALT between the group given 200 and $400 \mathrm{mg} / \mathrm{kg}$ was not statistically significant $(p>0.05)$. The level of ALT differs between the group given 400 and 600 $\mathrm{mg} / \mathrm{kg}$. Also, the level of ALT between the group given 200 and $600 \mathrm{mg} / \mathrm{kg}$ was significantly different $(p<0.05)$. There appeared to be no significant difference between the group given $400 \mathrm{mg} / \mathrm{kg}$ and the normal control whereas all the other two groups differed significantly from the normal control.

The result in the case of AST showed that the group given $200 \mathrm{mg} / \mathrm{kg}$ had a significantly different value for AST from all the other groups, including the normal control. The group given 400 and $600 \mathrm{mg} / \mathrm{kg}$ did not differ from each other but all of them differed significantly from the normal control $(p<0.05)$. The result in the case of ALP showed that the group given 200 and $400 \mathrm{mg} / \mathrm{kg}$ were not statistically different from each other $(p>0.05)$. Also, there was no significant difference between the group given 200 and $600 \mathrm{mg} / \mathrm{kg}$ but there was significant difference between the group given 400 and $600 \mathrm{mg} / \mathrm{kg}$. In general, there was significant difference between all the groups and the normal control $(p<0.05)$.

The result showed that in the case of serum urea, only the two concentrations 200 and $400 \mathrm{mg} / \mathrm{kg}$ were not statistically different $(p>0.05)$ but comparison between all the other concentrations with each other and also with the normal control were statistically significant $(p<0.05)$. The result in the case of creatinine showed that comparisons between all the groups with one another and also with the normal control were not significantly different $(p<0.05)$ in each case.

\section{DISCUSSION}

The result of the phytochemical screening carried out on the aqueous extract of the stem bark of $B$. dalzielli showed the presence of alkaloid, flavonoid, tannins, saponins, balsam, cardiac glycoside, terpenes, steroids, resins, and phenols. The organs responsible for the metabolism of xenobiotics, including medicinal plants are 
Table 2. Effect of the oral administration of aqueous extract of Boswellia dalzielli stem bark on serum urea level.

\begin{tabular}{lc}
\hline Group (mg/kg) & Urea (mmol/L) \\
\hline $1(200)$ & $5.23 \pm 0.16^{\mathrm{a}}$ \\
$2(400)$ & $5.60 \pm 0.27^{\mathrm{a}}$ \\
$3(600)$ & $3.53 \pm 0.06^{\mathrm{b}}$ \\
4 (normal control) & $6.40 \pm 0.10^{\mathrm{c}}$ \\
\hline
\end{tabular}

All values are expressed as mean mean \pm standard deviation of four replicates. Values with different superscripts down the column for example a, b, c,

Table 3. Effect of the oral administration of aqueous extract of Boswellia dalzielli stem bark on serum creatine level.

\begin{tabular}{lc}
\hline Group (mg/kg) & Creatinine (mmol/L) \\
\hline $1(200)$ & $62.33 \pm 0.58^{\mathrm{a}}$ \\
$2(400)$ & $59.33 \pm 1.53^{\mathrm{a}}$ \\
$3(600)$ & $61.00 \pm 2.65^{\mathrm{a}}$ \\
4 (normal control) & $60.00 \pm 1.00 \mathrm{a}$ \\
\hline
\end{tabular}

All values are expressed as mean \pm standard deviation of four replicates. Values with different superscripts down the column are statistically different at $(p<0.05)$.

Table 4. Effect of the oral administration of aqueous extract of Boswellia dalzielli stem bark on alanine amino transferase (ALT) level.

\begin{tabular}{lc}
\hline Group (mg/kg) & ALT (IU/L) \\
\hline $1(200)$ & $26.00 \pm 1.00^{\mathrm{a}}$ \\
$2(400)$ & $28.33 \pm 1.53^{\mathrm{ac}}$ \\
$3(600)$ & $49.33 \pm 1.53^{\mathrm{b}}$ \\
4 (normal control) & $33.00 \pm 1.00^{\mathrm{c}}$ \\
\hline
\end{tabular}

All values are expressed as Mean \pm standard deviation of four replicates. Values with different superscripts down the column for example a, b, and c, are statistically different at $(p<0.05)$.

the liver and kidney. Therefore, in studying the toxic effects of any xenobiotics involving the dose response relationships, emphasis should be made on the biomarkers of response of these two organs which are necessary for the establishment of the No observed adverse effect level (NOAEL) and/or the toxic level of a xenobiotics (Donald and Johnnie, 2001).

The index of liver functions showed a significant decrease in the case of ALT in the groups given 200 and $400 \mathrm{mg} / \mathrm{kg}$ compared to the normal control. This is not indicative of liver damage which usually causes an increase in this parameter, but the higher concentration $(600 \mathrm{mg} / \mathrm{kg}$ ) showed a significant increase compared to the normal control which is an indication that there might be some damage to the liver cells. There is an increase
Table 5. Effect of the oral administration of aqueous extract of Boswellia dalzielli stem bark on serum aspartate amino transferase (ASAT) level.

\begin{tabular}{lc}
\hline Group (mg/kg) & AST (IU/L) \\
\hline $1(200)$ & $108.00 \pm 1.00^{\mathrm{a}}$ \\
$2(400)$ & $121.33 \pm 0.58^{\mathrm{b}}$ \\
3 (600) & $122.33 \pm 0.58^{\mathrm{b}}$ \\
4 (normal control) & $89.00 \pm 1.00^{\mathrm{c}}$ \\
\hline
\end{tabular}

All values are expressed as Mean \pm standard deviation of four replicates. Values with different superscripts down the column for example a, b, and c, are statistically different at $(p<0.05)$.

Table 6. Effect of the oral administration of aqueous extract of Boswellia dalzielli stem bark on serum alkaline phosphatase (ALP) level.

\begin{tabular}{ll}
\hline Groups (mg/kg) & ALP (IU/L) \\
\hline $1(200)$ & $24.61 \pm 0.35^{\mathrm{a}, \mathrm{b}}$ \\
$2(400)$ & $24.26 \pm 0.12^{\mathrm{a}}$ \\
3 (600) & $23.52 \pm 0.47^{\mathrm{b}}$ \\
4 (normal control) & $26.19 \pm 0.10^{\mathrm{c}}$ \\
\hline
\end{tabular}

All values are expressed as Mean \pm standard deviation of four replicates. Values with different superscripts down the column for example a, b, and c, are statistically different at $(p<0.05)$.

in the level of serum AST in all the treatment groups compared to the normal control. This could be as a result of liver damage caused by the administration of this extract as has been confirmed by literatures that there is an increase in the level of AST activities in liver diseases that affect both mitochondrial and cytoplasmic membranes (Martin, 2006).

The serum level of ALP showed a significant decrease in all concentrations (200, 400 and $600 \mathrm{mg} / \mathrm{kg}$ ) compared to the normal control. This finding is not clearly indicating liver disease, and hence not in concordance with other findings using ALP which reported an increase in the level of ALP in cholestic liver disease (Jaschke et al., 2002). In general, there is an increased level of AST compared to ALT, which is an indication of damage to both the mitochondrial and cytoplasmic membranes of the liver. Literatures also attested to this fact (Martin, 2006). The serum urea concentrations between 200 and $400 \mathrm{mg} / \mathrm{kg}$ appeared to show no difference but was different from $600 \mathrm{mg} / \mathrm{kg}$ and it also decreased significantly $(p<0.05)$ in all the groups compared to the normal control. This could be as a result of increase in the glomerular filtration rate of the kidney, leading to the excretion of more urea in the urine as reported by James et al. (1998).

The serum level of creatinine appeared to have no significant difference $(p<0.05)$ among all the groups $(200,400$ and $600 \mathrm{mg} / \mathrm{kg}$ ) with the normal control. This is 
an indication that there is no renal dysfunction with the administration of all the three different concentrations of the extract.

\section{CONCLUSION}

There appeared to be a decrease in ALT and ALP in comparison with the normal control. But the level of AST is higher, indicating possible liver damage, and this is also evident by the reduced serum level of urea but the extract in all the three different concentration had no difference with the normal control in the case of AST. Hence, it was concluded that the extract had toxic effect on the liver but had no toxic effect on the kidney of the mice.

\section{REFERENCES}

Coomb's J (1989). Medicinal plants. Macmillan Dictionary of Biotechnology. London. Macmillan Limited pp. 330.

Donald JD, Johnnie RH (2001). Principles and methods of toxicology. fourth Edition, Edited by A. Wallace Hayes, Taylor and Francis. Pp. 77-130.

Goldman P (2001). Herbal Medicines Today and the root of modern pharmacology. Annals Int. Med. 135:594 - 600.

Hussin AHJ (2001). Adverse effects of Herbs and Drugs - Herbal Interactions. Malaysian J. Pharm.1(2):39-44.

Jacshke H, Gores GJ, Cederbaum AH, Hinson JA, Pessayre D, Lemasters JJ (2002). Mechanism of Hepatotoxicity. Toxicol. Scie. 65(2):105-14.

James W, Lohr Gail RW, Margaret AA (1998). Renal drug metabolism. Biochemical.89:1123-1142.

Johnstone BA (1997). One thirds of nation's adults use herbal remedies. Herbal gram. 40:49.

Martin AC (2006). Clinical chemistry and metabolic medicine. Seventh Edition. pp. 36-57.
Moses AO, Yvonne TK, John DM (2005). The antimicrobial activity of methanol extract of the stem bark of Boswellia Dalzielli. J. Pharm. BioResour. 2(2): 131-136.

Murray M (1995). The healing power of herbs. Prima Publishing, Rocklin, C. A. P. pp. 162-171.

Nwogwu LA, Igwe CU, Emejulu, (2008). Effect of landolphia owariensis leaf extract on the liver function profile and haemoglobin concentration of albino rats. Afr. J. Biochem. Res. 2(12):240-242.

Odesanmi SO, Lawal RA, Ojokuku SA (2009). Effects of ethanolic extract of tetrapleura tetraftera on liver function profile and histopathology in male Dutch White Rabbits. Int. J. Trop. Med. 4(4): 136-139.

Sofowora, A. (1993). Medicinal plants and traditional medicine in Africa, Second Edition Spectrum Books Ibadan Pp. 150.

Tripathi L, Tripathi JN (2003). Role of Biotechnology in Medicinal Plants. Trop. J. Pharm. Res. 2:243-253. 